https://doi.org/10.22364/htqe.2019.09

\title{
THE VARIETY OF VISUAL MEANS OF EXPRESSION IN CREATIVE WORK OF STUDENTS
}

\author{
Ilze Kadiḳe \\ Mg. educ., Latvian Academy of Culture, Latvia
}

\begin{abstract}
This article is part of a more comprehensive study of the use of artistic (visual) means of expression in nowadays' visual communication. The author has sought an answer to the question if the strategies developed in the course of centuries for how to embody spatial constructions in a two-dimensional reflection are present not only in professional artists' but also in highschool students' creative work. Every student can analyse the performance of an artist as an information bearer and a skilful arranger of the means of artistic expression, and consequently every student can discover new for themselves means of visual expression, their arrangement principles in an artwork, and they can also recognize cultural contexts such as signs, symbols, archetypes, narratives etc.

In order to gain a deeper understanding of the situation, the author has analysed the legislative basis regulating the cultural education in Latvia. The study focuses on the quantitative analysis of the means of artistic and visual expression the students have observed and listed as present in certain works of art. The ability to use the acquired knowledge in their own creative assignments has also been analysed. The focus group of the study are students at the General Secondary Education Distance Learning Program of the Riga Distance Education Secondary School. The obtained data provide a quantitative overview also on the mentions of the means of artistic expression in the study books in order to compare traditional and innovative appliance of the means of artistic expression.

Keywords: educational system of Latvia, art education, visual literacy of students, means of expression in visual arts, general secondary education, teaching aids.
\end{abstract}

\section{Introduction}

Continuous and rapid change is taking place in today's world. As a result, there is a growing need for self-determination and identity awareness. In 
this context, 'cultural awareness and expression' in the European Union's (EU) education guidelines is rightly called competence. Cultural awareness involves understanding of the local, national and European cultural heritage and its place in the world. It includes basic knowledge of the most outstanding cultural creations, including those representing popular contemporary culture and contemporary art. Competence of cultural awareness and self-expression is not possible without the individual's visual literacy, which is a specific competence that implies that a person (student) is able to react individually to creative expressions or to act creatively (creativity) that he / she can present (exhibit) his / her creative work and is able to collaborate with others - the skill that is called social competence, that he / she is able to choose the type and techniques that would help to create one's artwork - this skill is called methodological competence. The paper would name the most important normative documents in force in Latvia that define culture and art education in formal education, as well as the process of change in education or reform (see - I. Regulatory Framework for Cultural and Art Education in General Secondary Education).

The aim of the study is to answer the question if a student can acquire visual literacy skills at a general secondary school up to such a level to be able to successfully communicate by acquiring and applying visual means of expression?

In the Riga Distance Education Secondary School, the study work is organized in such a way that despite the students are not present at the educational institution (pupils studying outside of Latvia because of work or other family circumstances), they can nevertheless acquire new knowledge and skills at the time and in the way they want. The unique electronic website of the school provides specially designed methodical teaching aids, such as a thematic outline of the curriculum with theoretical explanations in the subject, self-test tasks for each subject taught, comparative, analytical and creative tasks to be performed following strict or partial requirements, such as experimenting or freely choosing the artistic technique (from drawing and painting techniques on paper to computer graphics) and materials. Full-time webinars are recorded so that students can repeatedly listen to the topics that are presented and might be interesting to them. In order to successfully pass the tests of various contents and difficulty, students must develop self-directed learning skills by selecting and using the learning literature themselves (see - Study literature 2), - the ability to motivate themselves for learning, - the ability to prepare their own work environment and provide the tools they need, to communicate with classmates and educators for clarifying the unclear matters, and to develop collaborative skills. The article analyzes the awareness of the Visual Arts students regarding the means of expression of visual art, their ability to 
recognize, compare and describe them by studying distinguished cultural patterns - paintings and graphics (this time posters will be discussed, see: III.). The next task is to analyze quantitatively how the students named and listed means of expression as well as how they applied them in their own creative work. The ability of students to choose and creatively "arrange" the means of visual art expression in their own creative work will not only be the starting point for successful visual communication, but also enables an implementation of a quality learning process. A deeper analysis of the students' creative work or their "visual messages" however will not be provided in the article.

If we go along with the theory provided by the academician and art theorist William J. T. Mitchell stating that nowadays the model of the world is designed by visual images, as the visual (visible, viewable) world dominated the verbally expressed, spoken text (the word), then it is necessary to develop a complex learning process with interdisciplinary application of skills in order to provide a visual communication experience to the students (Mitchell, 1980). That is why the research question needs to be repeatedly asked in order to find out whether students' understanding of the use of the means of visual art expression in an artwork is revealed in the ability to apply them to their own creative works.

\section{Normative acts regulating culture and arts education as part of general secondary education}

There are a few normative acts of the Republic of Latvia regulating topics related to cultural education and expression. The first to be mentioned is the Sustainable Development Strategy for Latvia 'Latvija 2030' (Ministry of Environmental Protection, 2010) stressing the requirement for qualitative education that would be available throughout the lifetime and oriented towards creativity in order to react to the challenges of the global competition and demographic tendencies. The National Plan for Development (NPD 2014 - 2020) defines that it is necessary for a person to develop a variety of competencies, while the Basic Statements for Cultural Policy 2014 - 2020 'The Creative Latvia' ('Radošā Latvija') is a medium term policy planning document aiming to confirm the value of culture and to define policies for diverse and sustainable development of culture that could support the growth and the potential for competitiveness of the state as well as ensure higher quality of life for everyone by preserving and developing the cultural capital and the creativity of the inhabitants of Latvia (Latvijas vēstnesis, 2017).

Latvia hosts a wide variety of multifaceted cultural events in educational institutions such as kindergartens, schools (including art schools with a 
professional focus) and universities as well as in cultural institutions such as museums, libraries, cinemas and theatres, cultural and educational centres, community houses and art studios, furthermore, in cultural events like the Song and Dance Festival, art festivals and symposia. Each of cultural events helps an individual (including students) to discover and acquire important knowledge and skills as well as to learn more about the means of artistic expression. In the context of this study the week of creative activity "Radošās darbības nedēḷa radi! 2016" (Creative Week - Create! 2016) should be mentioned as it allowed to view the actualization of the necessity to develop visual literacy from a new, slightly different angle.

The week of creative activity "Radošās darbības nedēla radi!2016" (Creative Week - Create! 2016) took place in Latvia in May 2016 (the event repeats on annual basis since 2012, and it could equally be named also the week of visual literacy or the week of UNESCO Art education. This week allowed demonstrating the success in preserving traditions and developing interest education in Latvia. The event hosted the conference "Cultural and Arts education: Create Yourself in a School!" having invited Prof. Ernst Wagner - expert of art and media education, Chair of the Cultural Council of the National UNESCO Commission of Germany, co-author of the European Framework of Reference in Visual Literacy. Conference participants representing the National Centre for Education (NCE) of Latvia, National UNESCO Commission of Latvia, Latvian Academy of Culture, University of Latvia, Jāzeps Vìtols Academy of Music of Latvia, other higher education institutions as well as teachers and art education experts discussed the importance of the development of visual literacy for individual as a today's creative process actor in order to ensure a successful visual communication not only in the local but also in European context.

It shall be mentioned that UNESCO scope of art and culture education comprises two inseparable and simultaneously implementable approaches: learning about arts and culture and learning via arts and culture. It implies that every individual has rights to participate in artistic and cultural processes both as a consumer and a creator, bearing in mind that arts and culture develop not only the inherent creative potential of an individual, but also serves as a tool for the development of the personality, talents, intellectual and physical abilities (UNESCO in Latvia, 2016). In 2016 the National Centre for Education (NCE) of Latvia, supported by a policy initiative launched by the Ministry of Education of Latvia and European Structural Funds, started implementing an education project No 8.3.1.1./16/1/002 "Educational Curriculum and Learning Approach" (hereinafter the project Skola 2030). The project suggests that "the understanding of the knowledge and skills that will be needed in the society in the future is changing not only in Latvia, but also elsewhere in the world. Overall, pupils in Latvia are 
good in tasks requiring to remember or act in known situations, however, they lack skills and experience to get deeper, process various data, work as a team, offer solutions for non-standard situations. Therefore, schools should attempt to offer children and youths such learning experience, which would results in pupil's expertise or competence: the ability to use knowledge, skills and express attitudes in a complex way, solving problems in various real-life situations"(Project Skola 2030, 2017).

The purpose of general secondary education has been defined as the following in the project description: "The purpose of general secondary education is to allow each student to become a goal-oriented and skilled collaborator at shaping their professional future, one that cooperates and is a patriot of Latvia, that has enriched their knowledge, skills and approaches required by a knowledge-based society according to her goals, and that innovatively and productively participates at growth of economics, welfare and sustainability in her homeland and the world (Project Skola 2030, 2017). The curriculum has been addressed to pupils from 1.5 years of age to the age 18 when they complete secondary education. Henceforth the curriculum has been divided into three stages, pre-school, elementary school and secondary school education. For each grade the curriculum has been divided into fields as the following for elementary school education: Languages, Social and Civic, Cultural Understanding and Self-Expression in Arts, Natural Sciences, Mathematics, Technologies, Health and Physical Activity. The field Cultural Understanding and Self-Expression in Arts (hereinafter Self-Expression in Arts) as part of elementary school education provides pupils with an opportunity to discover and develop their creative talents, knowledge, skills and techniques in four artistic practices (teachers often qualify them as learning subjects): music, drama, visual arts and literature. Self-expression in arts is divided into sub-elements:

- forms of art

- creation of ideas

- practical assignments

- assessment and interpretation

- ethical and aesthetical experience

- Cultural contexts.

Discussing the subject requires developing an understanding of visual means of expression which proposes how the general ideas are suggested by the Forms of Art sub-faculty: "Each form of art has its particular characteristic means of artistic expression" (Project Skola 2030, 2018) and, for instance, after finishing grade 3 (at age 9) a pupil must be able to distinct the simplest means of artistic expression such as lines, plains, forms and colours and apply them for experiments and gaining experience; after grade 6 (at age 12) a pupil must be able to distinct several means of 
visual artistic expression such as line, plain, volume, colour, light, texture, and basic principles of composition such as balance, contrast, rhythm, proportions and perspective as well as to be able to gain experience by applying them; finally, after grade 9 (at age 15) a pupil shall be able to characterize the means of artistic expression of different fields of art, including cinematography, design and architecture and to assess their combinations oriented towards diverse purposes and meanings.

In the scope of the newly developed normative regulations for primary and general secondary education it can clearly be seen that in the future it will continue to be necessary to ensure that students master visual literacy involving also the awareness of the visual means of expression.

\section{Literature used for the subject "Visual Art"}

An up-to-date (complex and interdisciplinary) cultural and arts education can be implemented gradually by supporting the whole education system (here referring to educational institutions of all levels and directions) by a good methodical reference system that provides contemporary textbooks as the primary sources of knowledge.

Art education of then claims for the usage of additional sources, for instance, art history books, autobiographies of artists, periodicals etc., however these materials cannot replace curriculum textbooks that ensure methodical knowledge building and a multiplicity of assignments in accordance with the age group of the students. Following the first step in the Foucauldian strategy, namely, to reflect upon the practice ${ }^{1}$, the attention will be paid to those textbooks applied as part of the curriculum in a longer run; respectively, the textbooks published in the end of the $20^{\text {th }}$ century and are not applied anymore (examples 1-3), as well as the textbooks published in the $21^{\text {st }}$ century and are still in appliance (examples 4-6).

As the first example the methodical tool for teachers 'Visual Art for Grades 1-6. Means of Expression and Techniques' published in 1985 by Valentīna Hibnere, Lilija Grasmane and Valdis Villerušs (Hibnere, Grasmane, Villerušs, 1985) should be mentioned. The textbook systematizes the basic statements referring to the artistic creativity of the schoolkids, describing the two-dimensional means of artistic expression and the techniques. The mentioned means of artistic expression that graphics, painting and collage have in common are the following: ground, silhouette, shape, spatiousness, colour, colour spot, texture. As typical means of artistic expression for graphics are mentioned dots, lines, dashes, hatching.

${ }^{1}$ According to Michel Foucault, this strategy refers to knowledge building systematized in local practices or predetermined problems. 
As another example can be mentioned the methodical tool for teachers 'The ABC of the visual arts language' by Vaiva Zirdzina, published in 1995. The book contains the list of sources mentioning worldwide known art and art education theorists such as Betty Edwards, Rob Barnes, Mona Brookes, Charles D.Gaitskell, Ernst A. Weber, Winfried Nerdinger a.o. The author describes visual means of expression as follows: "The perception of visual art begins with the perception of the outer, visible level of the artwork. The basic elements of the visible level structure are visual elements. (..) Each kind of art - sound, word, movement, visual arts - has its own specific language. Visual arts language is the 'footprint' of usage of materials and tools, and each line, colour spot, or curved shape drawn by an artist; an architect or a designer has its sense and meaning. 'The author describes the most important visual elements: colour and shape, movement, line, texture, darklight (chiaroscuros). The author also mentions the principles of composition or means of creating an unified artwork - harmony (rhythm), diversity or difference (contrast), balance (symmetry, asymmetry), proportion, movement (dynamics), center of attention (domination), simplicity (economy) principle, space a.o. (Zirdziña, 1995).

As the third example the pilot-project methodical tool "How painting, engraving, sculpture are made" (1998) by Daina Blūma and Edvarda Šmite should be mentioned. The title of the book refers to the variety of artworks representing painting, graphics and sculpture and to the descriptions of techniques that help to understand the differences and the most essential features for each kind of art. The authors do not focus on visual means of expression because that would not be the main aim of the book, however, they refer to visual means of expression in a descriptive way. Visual means of expression are mentioned with a reference to painting: colour, colour spot, line, chiaroscuros, shape and space, plane with a characteristic height and width. The authors note that the linear, air and colour perspective are distinguished, as well as the inverted or reverse perspective. Subordinating individual elements of a painting to a common purpose serves to create the composition of a painting. Separately, visual means of expression in graphics are mentioned - line, chiaroscuros, tones and halftones, dark and light areas (Blūma, Šmite, 1998).

The fourth reviewed textbook "Visual Art for High School. Part 1" (2009) and "Visual Arts for High School. Part 2" (2010) is a collaborative work by Ilze Briška, Ilze Kadik,e, Daiga Kalēja-Gasparoviča and Maija Rudovska. "The reality of life that we are looking for in a painting is, on the one hand, life events, facts, persons, objects. On the other hand, a more or less realistic or less realistic visual form that the author assigns to the artwork is the perception of reality as a point of reference for the author's analysis of the painting. In the chapter "Art as a World Observation", the book deals 
with the perception of vision, by which visual means of expression are understood: outline, background, tint, colour, and the relationship among these visual elements. "Points are grouped in lines and squares. Then all the information about each point of the visual field - its shade, colour and positiom - is transmitted to the human brain, where the visible world is composed as a puzzle; the picture is flat, the entire surface of the image is reflected in the same way as a computer display. "In the other chapters of the book, means of expression are mentioned: shape, proportion, direction (vertical, horizontal, dynamic) or motion, contrast, and various" dynamic forces" or characteristic values and characteristics such as rhythm, pace, character, energy, strength, tension (Briška, Kadik̦e, Kalēja-Gasparoviča, Rudovska (2010)).

The fifth and the newest source referred to in this review, the methodical tool "Interface Art. Computers. Graphics. Design" (Kūlis, 2015) by Matīss Kūlis, the researcher of the Insititute of Mathematics and Computer Science at the University of Latvia, should be mentioned. The methodical source not only describes new aspects of the field of information and communication technology, but also talks about creativity, artistry and about "making one's work with the computer more delightful". "More than ever, we are surrounded by different screens ..." (Kūlis, 2015) suggests Kūlis while talking about the impact of computer technology on our lives. The author points out that casually the area of visual art occupied with content design is called graphic design. The book emphasizes the aesthetic function of interfaces, thus the list of the means of artistic expression mentioned in the methodical source can be used for art education studies. In the book, the author argues that in the development of the user graphical interface, the artistic aspects - composition, form, spatiousness (volume), space, colour, warm and cool colour relationship, line, rhythm, texture, decorativeness, expression, etc. are taken into account as much as possible. "Professionally balanced, all these means of artistic expression in user graphical interface design determine artistic quality," the author adds.

The last $\left(6^{\text {th }}\right)$ quantitative data column summarizes the means of visual art expression in the primary education curriculum (Republic of Latvia Cabinet. 2018). Table 1 provides an overview of the visual means of expression referred to in the reviewed sources. It also serves as an easy tool that allows to compare the means of visual expression listed in the methodical sources with those named by the students as well as allow a transparent comparison with the means of expression named by the students (error tolerance is allowed). 
Table 1. The most commonly used visual means of expression named in the textbooks and curriculum published in Latvia at the turn of the century $(n-6)$.

\begin{tabular}{|c|c|c|c|c|c|c|c|c|}
\hline 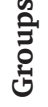 & No. & $\begin{array}{l}\text { Means of visual } \\
\text { expression }\end{array}$ & $\begin{array}{c}\text { Source } \\
1 *\end{array}$ & $\begin{array}{c}\text { Source } \\
2 *\end{array}$ & $\begin{array}{c}\text { Source } \\
3^{*}\end{array}$ & $\begin{array}{c}\text { Source } \\
4 *\end{array}$ & $\begin{array}{c}\text { Source } \\
5^{*}\end{array}$ & $\begin{array}{c}\text { Source } \\
6^{*}\end{array}$ \\
\hline \multirow{6}{*}{ 䛼 } & 1 & Point & & & & & & \\
\hline & 2 & Line & & & & & & \\
\hline & 3 & Stripe & & & & & & \\
\hline & 4 & Outline & & & & & & \\
\hline & 5 & Contouring line & & & & & & \\
\hline & 6 & Hatching & & & & & & \\
\hline \multirow{3}{*}{ 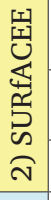 } & 7 & Texture & & & & & & \\
\hline & 8 & Finish & & & & & & \\
\hline & 9 & Surface properties & & & & & & \\
\hline \multirow{6}{*}{ 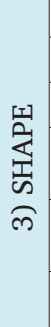 } & 10 & Field & & & & & & \\
\hline & 11 & Background & & & & & & \\
\hline & 12 & Silhouette & & & & & & \\
\hline & 13 & Form & & & & & & \\
\hline & 14 & Colour spot & & & & & & \\
\hline & 15 & Colour field & & & & & & \\
\hline \multirow{6}{*}{ 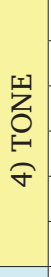 } & 16 & Light & & & & & & \\
\hline & 17 & Shade & & & & & & \\
\hline & 18 & Chiaroscuros & & & & & & \\
\hline & 19 & Tone & & & & & & \\
\hline & 20 & Tint & & & & & & \\
\hline & 21 & Colouring & & & & & & \\
\hline \multirow{3}{*}{ 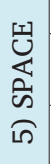 } & 22 & Volume & & & & & & \\
\hline & 23 & Figure & & & & & & \\
\hline & 24 & Spatiousness / space & & & & & & \\
\hline \multirow{8}{*}{ 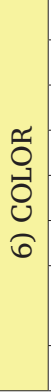 } & 25 & Colour & & & & & & \\
\hline & 26 & Achromatic colours & & & & & & \\
\hline & 27 & Chromatic colours & & & & & & \\
\hline & 28 & Primary colours & & & & & & \\
\hline & 29 & Secondary colours & & & & & & \\
\hline & 30 & Analogous colours & & & & & & \\
\hline & 31 & $\begin{array}{l}\text { Additionnal / comple- } \\
\text { mentary colour }\end{array}$ & & & & & & \\
\hline & 32 & Complementary colours & & & & & & \\
\hline
\end{tabular}




\begin{tabular}{|c|c|c|c|c|c|c|c|c|}
\hline 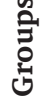 & No. & $\begin{array}{l}\text { Means of visual } \\
\text { expression }\end{array}$ & $\begin{array}{c}\text { Source } \\
1 *\end{array}$ & $\begin{array}{c}\text { Source } \\
2 *\end{array}$ & $\begin{array}{c}\text { Source } \\
3^{*}\end{array}$ & $\begin{array}{c}\text { Source } \\
4 *\end{array}$ & $\begin{array}{c}\text { Source } \\
5 *\end{array}$ & $\begin{array}{c}\text { Source } \\
6 *\end{array}$ \\
\hline \multirow{5}{*}{ 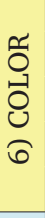 } & 33 & Cold colours & & & & & & \\
\hline & 34 & Warm colours & & & & & & \\
\hline & 35 & Local colour & & & & & & \\
\hline & 36 & Total colour & & & & & & \\
\hline & 37 & Hue & & & & & & \\
\hline \multirow{6}{*}{ 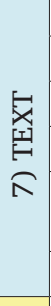 } & 38 & Text / letter & & & & & & \\
\hline & 39 & Sign & & & & & & \\
\hline & 40 & Symbol & & & & & & \\
\hline & 41 & Latvian ornamental sign & & & & & & \\
\hline & 42 & $\begin{array}{l}\text { Latvian ethnographic } \\
\text { ornament }\end{array}$ & & & & & & \\
\hline & 43 & Decorativity & & & & & & \\
\hline \multirow{8}{*}{ 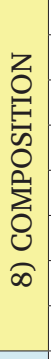 } & 44 & Composition & & & & & & \\
\hline & 45 & Rhythm & & & & & & \\
\hline & 46 & Contrast & & & & & & \\
\hline & 47 & Balance & & & & & & \\
\hline & 48 & Proportion & & & & & & \\
\hline & 49 & Domination & & & & & & \\
\hline & 50 & Economy / simplicity & & & & & & \\
\hline & 51 & Perspective & & & & & & \\
\hline \multirow{6}{*}{ 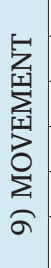 } & 52 & Movement / pace & & & & & & \\
\hline & 53 & Expressiveness & & & & & & \\
\hline & 54 & Energy & & & & & & \\
\hline & 55 & Dynamic forces & & & & & & \\
\hline & 56 & Scale & & & & & & \\
\hline & 57 & Direction & & & & & & \\
\hline
\end{tabular}

Source 1 is the methodical tool for teachers 'Visual Art for Grades 1-6. Means of Expression and techniques' by Valentīna Hibnere, Lilija Grasmane and Valdis Villerušs (1985);

Source 2 is the methodical tool for teachers 'The ABC of the visual arts language' by Vaiva Zirdzina (1995);

Source 3 is the pilot-project methodical tool "How painting, engraving, sculpture are made" by Daina Blūma and Edvarda Šmite (1998);

Source 4 is the textbook "Visual Art for High School. Part 1" (2009) and "Visual Art for High School. Part 2" (2010) by Ilze Briška, Ilze Kadik̦e, Daiga Kalēja-Gasparoviča and Maija Rudovska;

Source 5 is the methodical tool "Interface Art. Computers. Graphic. Design" by Matīss Kūlis (2015);

Source 6 is the primary education curriculum. 
The analysis of the aforementioned methodical tools allows to list the most popular means of visual expression used for visual communication in the time period of 30 years: line, form, spatiousness or space, colour and composition. It is worth mentioning that different authors may use different conceptual approaches towards these means of artistic expression. For instance, instead of being treated as means of artistic expression, composition is often enlisted separately as a method of arranging elements or perspective is described as a mathematical system transferring a 3D spatial object onto a flat surface.

In order to review the most significant means of artistic expression, they have been numbered and grouped according to similar traits:

1) line (point, line, stripe, outline, contouring line, hatching);

2) texture (texture, finish, surface properties) ;

3) shape (field, background, silhouette, shape, tonal field, colour spot, colour field);

4) tone (light, shade, chiaroscuros, tone, tint);

5) space (volume, figure, spatiousness / space);

6) colour (colour, achromatic colours, chromatic colours, primary colours, secondary colours, additional colours, complementary colours, cold colours, warm colours, local colour, total colour, hue, colouring);

7) text (text, letter, sign, symbol, Latvian ornamental sign, Latvian ethnographic ornament, rune, petroglyph, decorativity);

8) composition (rhythm, contrast, balance, proportion, dominant, economy, simplicity, scale, perspective);

9) Movement (movement, pace, expressiveness, energy, dynamic forces, scale, direction).

American professor Arthur Berger in his work Seeing is believing: An introduction to visual communication (Berger, 1989) explains such elements of visual communication as balance, composition, direction, lighting, perspective, proportion, colour, colour properties (tonality, intensity, brightness, warm and cold hues, colour harmony). The author suggests that such aspects as line, shape, volume, size, lighting, location, colour and perspective are able to transfer a message or symbolic information that affects the process of perception of visual images. Josiah Kahane, a design professor from Israel, in his article How Your Brain Understands Visual Language (Kahane, 2015), describes visual language and suggests that the concept of 'visual language' refers to visual perception, understanding and creating. Just like people can verbalize their thinking patterns, they can visualise them. A diagram, a map or a painting are all examples of the visual language. Its structural units include line, shape, colour, movement, texture, model, direction, orientation, scale, angle, distance and proportion 
(Kahane, 2015). The elements of a picture present concepts in space instead of presenting them in time like when speaking or reading. Spoken and visual communication is parallel and often interdependent means that help people to share information. If we refer to some other distinguished theories of visual communication then we can come to a conclusion that the range of the means of visual expression are unlimited, as often their properties are beyond those visually perceptible. In this study however the reference will be made to the visual means of expression listed in the most recent textbooks and methodical tools published in Latvia, with a scope on their usage as a set of criteria for evaluating creative works of the students.

\section{Students' perception of the means of visual expression}

The contents of the Arts Course as part of general secondary education in Latvia comprises three subjects: first, Literature which is mandatory, second, Visual Arts and third, Music. Both second and third faculties are optional which means that a student can choose one of them. The frequency of visual arts lessons is 40 minutes once per week in two years' time, while for distance learning this intensity is even more reduced, therefore self-tuition matters a lot. The visual arts course consists of online webinars, face to face classes and home assignments, both of theoretical and practical nature. Students also have to get acquainted with theoretical course materials on their own.

At Riga Distance Education Secondary School the pupils get acquainted with artworks representing the modernism and post-modernism in Latvia and worldwide, process the acquired theoretical knowledge, learn new means of artistic expression and master their application depending on individual skills, needs and requirements of the curriculum. The application of the means of artistic expression depends also on the objective to be reached, for example, if the objective is to perform an analysis of an artwork representing particular style or direction, the students have to result in a new visual composition, for instance, a drawing, a sketch, a painting or a photograph that should reveal how the principles of the relevant means of artistic expression or their composition are observed or, just the opposite, neglected. Assignments are purposefully orientated towards building an understanding of most important artistic trends predominating in certain chronological periods.

In order to trace similarities or regularities in the use of means of expression, an analysis of theoretical knowledge and practical appliance of the means of artistic expression as presented by the pupils of the subject "Visual art" will be provided. To identify students' ability to recognize and apply means of artistic expression, an example from grade 10 visual arts 
course addressed to students starting from 16 years of age has been selected. This is a test assignment of the difficulty level two. In the exercise, students have to analyze $20^{\text {th }}$ century artworks - posters representing different artistic trends. The first one represents the tradition of modernism and dates back to the beginning of the century. The second one refers to the end of the $20^{\text {th }}$ century and can be linked to postmodernism. One poster is a work of a world-renowned artist, and the other one has been created by a contemporary Latvian artist. The student first must choose one art work from two, then analysis of the work has to be carried out according to the following requirements: description of the label, the dominant, the type of the composition, the most prominent (at least three) means of expression, the type of the poster sorted by its meaning. It should be noted that every year the tests are changed, hence the images are changed too. That is the reason why the study involves only 50 students in each sampling (100 in total), and the assignment has two versions. Both of these versions will be analyzed.

The study group involves Riga Distance Education Secondary School students ( $n-100,25$ students each group) in the study year 2017/2018 (The article adheres to the Personal Data Protection Act. The research is coordinated with the educational institution). In the first version, the students have to analyze the posters "Who are you going to vote for?" (Figure 1) by the Latvian artist Juris Dimiters and the poster "I want you for U.S. Army" by James Montgomery Flagg. In the second version, the students have to analyze the posters "TV violence" created by the Latvian artist Egils Vitols and the poster "Help!" by Dmitry Moor. One of these works must be chosen and analyzed in detail. The students are allowed to choose their favorite image or the one that is easier for them to analyze. This principle also promotes the strategy of self-directed learning that encourages making their choices according to their abilities. 


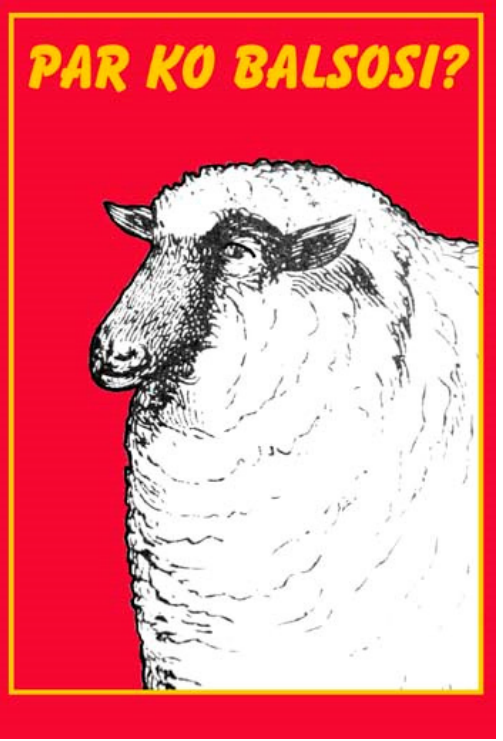

Figure 1. Juris Dimiters. Who are you going to vote for? Digital print. $100 \times 70 \mathrm{~cm} .2003$. Artist's property

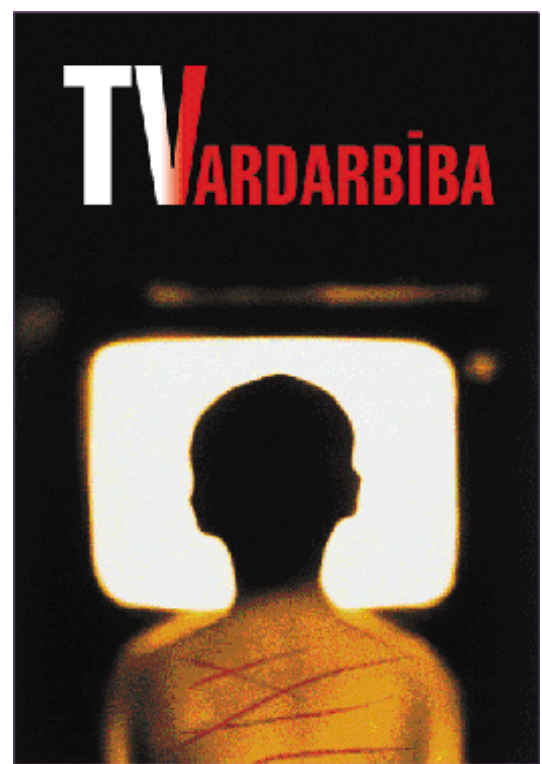

Figure 3. Egils Vìtols. TV violence. 2005. Digital print. Private collection

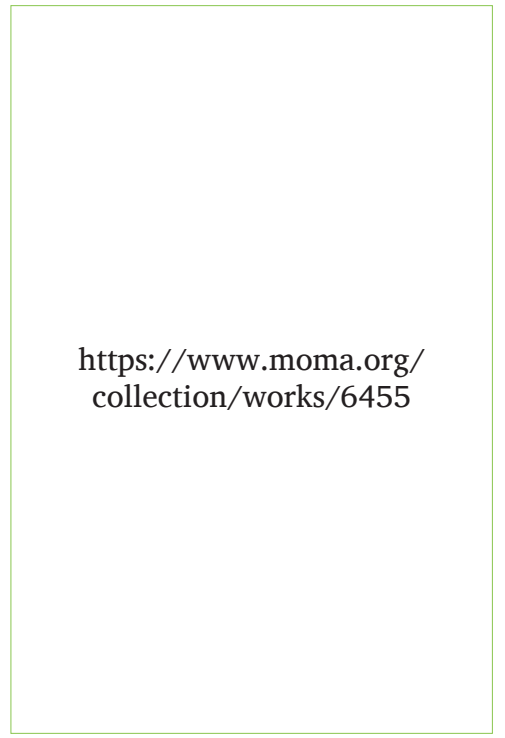

Figure 2. James Montgomery Flagg. I want you for U.S. Army. 1917. Paper litograph. Smithsonian American Art Museum

https://www.rsu.edu.ru/wpcontent/uploads/e-learning/ History_of_Art/Pictures/ Pict_75_1m.html

Figure 4. Dmitry Moor. Help!. 1921 
All the analyzed images are socio-political posters. Nevertheless, $1 / 4$ of the students considered posters 1 and 3 to belong to the social advertisement poster type. That could be influenced by the fact that the students have had a previous experience with media advertisement culture, such as advertisement promoting household appliances or political parties. Regarding posters 2 and 4, 1/7 of the students consider them to be propaganda posters. That can refer to Flagg's poster, but not to the one by Moor. Regarding naming at least three of the most visible (most prominent) means of artistic expression in the posters, the students used this opportunity and almost all responded by listing three options. Only $1 / 8$ of the students listed more means of artistic expression than required in the assignment, and $16 \%$ of the respondents did not name any means of artistic expression. Without careful consideration of all the answers, it can be concluded that the students do not know these means of expression. This statement is not justified though because all the students (including those who had not named any means of artistic expression) apply them nevertheless (see Figures 5 to 24). There are also cases (16\% of all the students) when none of the means of artistic expression are neither named nor used lacking creative work submissions. Nevertheless, even in this case no hasty decisions can be made, because there are several students with disabilities at the school who are not able to do practical creative work.

Analyzing these four posters, the students have mostly noted the "color" as a means of artistic expression - 32-88\% (Tables 2 and 3); In two cases, the color selection was compared with the colors of the flag, and the red color (16-24\%) was highlighted separately in both versions. If you add an achromatic or black and white color (40\%), the rate becomes even higher.

As the next most popular means of expression text / letters is named by $16-65 \%$ of all the tested students. The importance of letters perceived as signs has increased in nowadays' visual communication, since letters and text perceived as signs bear not only informative or phonetic information but also a visual and often - symbolic meaning. The meaning of a letter as a sign and symbol in today's visual communication has increased, as letters and text serve not only an informative (phonetic) function, but also bear a symbolic meaning. An example of this is the book-reading culture of the late 1980s-90s, which could be well observed even in the public transport, as people read periodicals and books with enthusiasm. In the USA during the 30 s of the $20^{\text {th }}$ century the development of a comic culture emerged later turning into a role-model of mass culture (Berger, 1989). In contrast, graphical communication of modern smart device (computer) users is based on a visual information perception model consisting of textual and graphical elements (Kūlis, 2015). It is also necessary to remember the unique Latvian 
characters, each of which has a semiotic meaning alike to Scandinavian runes. Valdis Celms, Latvian ornament researcher and designer, has stated: "An ornament must be firstfully perceived as a structure [..]. In its origin, ornament, just alike the spoken language is both a natural occurence and a cultural product"'(Celms, 2007).

The next means of expression is line, with $12-64 \%$ of the students referring to it. In print art line is the most distinctive means of expression, so a higher number of mentions were expected. In a distance learning school the most part of learning is self-directed, so it is very important to motivate the students to take on initiative. To make it work, it is important to start with baby steps, that is, if you want a student not to be afraid of doing creative work, in the beginning they shall be allowed to draw a sketch freely with the materials they like or have easily available. It must be noted that there were higher demands regarding creative work earlier, so a decision was made to reduce the requirements, for example, in one of the tests painting has been replaced by drawing or even sketching. This has brought results because there is an increasing number of students who choose to do creative work. For this test, there are $16 \%$ of students who do not perform creative work within the framework of this test, then beforehand the number was much higher, about one third of the students.

One means of expression that is often referred to in the second version of the test is contrast (32\%). Such test results provide a direct feedback on the students' understanding of the issue and their ability to detect the most important or essential. It should be noted that these skills are trained already in the $7^{\text {th }}$ grade of primary school as the means of artistic expression and the principles of the composition of the basic elements of an image are discussed. In his book "Interface Art. Computers. Graphic. Design" (Kūlis, 2015) Matīss Kūlis suggests that already in the beginning of the $20^{\text {th }}$ century painters were looking for the most important elements of the visual perception of people, and as such they named color, brightness and line. If we replace the term "brightness" with "contrast" (which is basically not wrong because the contrast enhances the perception of color), we can conclude that the students repeat the statements made at the beginning of the $20^{\text {th }}$ century in this task. On the other hand, it is only natural since the assignment actually deals with the works of the beginning of the $20^{\text {th }}$ century - even they do not represent the Mecca of arts: France (the methodic tool used in the curriculum presents also works by Henri de Toulouse-Lautrec, Henry van de Velde, Alfons Mucha and others).

The rest of the means of artistic expressions mentioned by the students are listed in tables 2 and 3 (on the sides of the tables there are data according to the test versions but the total result can be seen in the middle 
of the table, in the green column). Thematically the means of artistic expression are enlisted under the respective numbers (see Table 1). The expressions have left unchanged based on the answers of the students.

Table 2. Means of artistic expression (MAE) named by year 10 students (test version 1 , school year $2017 / 2018 ; n-50$ )

\begin{tabular}{|c|c|c|c|c|c|}
\hline & No. & $\begin{array}{l}\text { Rate of MAE } \\
(\%, n-25)\end{array}$ & $\begin{array}{c}\text { MAE in the poster } \\
\text { "Who are you going } \\
\text { to vote for?" }\end{array}$ & $\begin{array}{l}\text { MAE in the post- } \\
\text { er "I want you } \\
\text { for U.S. Army" }\end{array}$ & $\begin{array}{c}\text { Rate of MAE } \\
(\%, n-25)\end{array}$ \\
\hline \multirow[t]{3}{*}{1} & 1 & 8 & Point & - & - \\
\hline & 2 & 64 & Line/stripe & Line/stripe & 40 \\
\hline & 5 & - & & Countour line & 4 \\
\hline 2 & $\begin{array}{l}7 \\
8\end{array}$ & - & $\begin{array}{c}\text { Texture } \\
-\end{array}$ & Texture/finish & $\begin{array}{c}32 \\
8\end{array}$ \\
\hline \multirow[t]{5}{*}{3} & 10 & 16 & Field & Field & 8 \\
\hline & 11 & 8 & Background & - & - \\
\hline & 12 & 16 & Silhouette & Silhouette & 32 \\
\hline & 13 & 8 & Shape & shape & 24 \\
\hline & $\mathrm{x}$ & 4 & Frame & - & - \\
\hline \multirow[t]{2}{*}{4} & 16 & 16 & Chiaroscuro & - & - \\
\hline & 21 & - & - & Colouring & 8 \\
\hline 5 & 24 & - & - & Space structure & 8 \\
\hline \multirow[t]{9}{*}{6} & 25 & 72 & Colour & Colour & 88 \\
\hline & 32 & 8 & Opposite colour & Opposite colour & - \\
\hline & 28 & 8 & Red colour & Red colour & 24 \\
\hline & 28 & 8 & Yellow colour & Yellow colour & 8 \\
\hline & 28 & - & - & Blue colour & 8 \\
\hline & $\mathrm{x}$ & - & - & Flag colours & 8 \\
\hline & $\mathrm{x}$ & - & - & Bright colours & 8 \\
\hline & $\mathrm{x}$ & - & - & $\begin{array}{l}\text { Contrasting co- } \\
\text { lours }\end{array}$ & 8 \\
\hline & & 4 & White colour & White colour & 4 \\
\hline \multirow[t]{3}{*}{7} & 38 & 16 & Text/letters & Text/letters & 56 \\
\hline & $\mathrm{X}$ & 8 & Headline & Headline & - \\
\hline & 40 & 24 & Symbol & Symbol & 8 \\
\hline \multirow[t]{2}{*}{8} & 44 & & - & Composition & 32 \\
\hline & 46 & - & - & Contrast & 8 \\
\hline
\end{tabular}




\begin{tabular}{|c|c|c|c|c|c|}
\hline & No. & $\begin{array}{l}\text { Rate of MAE } \\
(\%, n-25)\end{array}$ & $\begin{array}{l}\text { MAE in the poster } \\
\text { "Who are you going } \\
\text { to vote for?" }\end{array}$ & $\begin{array}{l}\text { MAE in the post- } \\
\text { er "I want you } \\
\text { for U.S. Army" }\end{array}$ & $\begin{array}{c}\text { Rate of MAE } \\
(\%, n-25)\end{array}$ \\
\hline \multirow[t]{2}{*}{9} & $\mathrm{x}$ & 8 & Personification & - . & - \\
\hline & $\mathrm{x}$ & - & - & Phonetic MVE & 4 \\
\hline \multirow[t]{2}{*}{10} & $\mathrm{x}$ & - & - & $\begin{array}{c}\text { Man } \\
\text { Uncle Sam } \\
\text { Man showing }\end{array}$ & $\begin{array}{c}16 \\
8 \\
4\end{array}$ \\
\hline & $\mathrm{x}$ & 12 & Sheep & - & - \\
\hline 11 & $\mathrm{x}$. & 4 & Graphics & - & \\
\hline
\end{tabular}

Table 3. Means of artistic expression (MAE) named by year 10 students (test version 2, school year 2017/2018; n - 50)

\begin{tabular}{|c|c|c|c|c|c|}
\hline & No. & $\begin{array}{c}\text { Rate of MAE } \\
(\%, n-25)\end{array}$ & $\begin{array}{c}\text { MAE in the poster } \\
\text { "Who are you going } \\
\text { to vote for?" }\end{array}$ & $\begin{array}{l}\text { MAE in the post- } \\
\text { er "I want you } \\
\text { for U.S. Army" }\end{array}$ & $\begin{array}{c}\text { Rate of MAE } \\
(\%, n-25)\end{array}$ \\
\hline \multirow{4}{*}{1} & 1 & 8 & Point & - & - \\
\hline & 2 & 12 & Line / stripe & Line / stripe & 40 \\
\hline & 5 & - & - & Contouring line & 8 \\
\hline & 6 & 8 & Hatching & - & - \\
\hline 2 & $\begin{array}{l}7 \\
8\end{array}$ & 16 & Texture & Texture & 32 \\
\hline \multirow{5}{*}{3} & 10 & 16 & Field(s) & - & - \\
\hline & 11 & & - & Background & 40 \\
\hline & 12 & 16 & Silhouette & Silhouette & 16 \\
\hline & 13 & 16 & Shape & - & - \\
\hline & $\mathrm{X}$ & 4 & Frame & - & - \\
\hline \multirow{2}{*}{4} & 16 & - & - & Tones & 16 \\
\hline & 21 & - & - & - & - \\
\hline 5 & 24 & 8 & Spatiousness & - & - \\
\hline \multirow{4}{*}{6} & 25 & 80 & Colour & Colour & 32 \\
\hline & 32 & 8 & Opposite colour & Opposite colour & 8 \\
\hline & 28 & 16 & Red colour & Red colour & - \\
\hline & 26 & 8 & $\begin{array}{l}\text { Black and white } \\
\text { colour }\end{array}$ & $\begin{array}{l}\text { Black and white } \\
\text { colour }\end{array}$ & 40 \\
\hline \multirow{3}{*}{7} & 38 & 48 & Text / letters & Text/letters & 40 \\
\hline & $\mathrm{X}$ & 24 & Headline & Caption & 8 \\
\hline & 40 & 16 & Symbol & Symbol & 16 \\
\hline
\end{tabular}




\begin{tabular}{|c|c|c|c|c|c|}
\hline & No. & $\begin{array}{l}\text { Rate of MAE } \\
(\%, n-25)\end{array}$ & $\begin{array}{l}\text { MAE in the poster } \\
\text { "Who are you going } \\
\text { to vote for?" }\end{array}$ & $\begin{array}{l}\text { MAE in the post- } \\
\text { er "I want you } \\
\text { for U.S. Army" }\end{array}$ & $\begin{array}{l}\text { Rate of MAE } \\
(\%, n-25)\end{array}$ \\
\hline \multirow{2}{*}{8} & 44 & 24 & Composition & Composition & 32 \\
\hline & 46 & 32 & Contrast & Contrast & 16 \\
\hline \multirow{2}{*}{9} & $\mathrm{X}$ & 8 & Metaphor & - & - \\
\hline & $\mathrm{X}$ & 8 & Plot & Hunger & 4 \\
\hline \multirow{5}{*}{10} & $\mathrm{X}$ & 44 & $\begin{array}{l}\text { Human figure / a } \\
\text { man / the main } \\
\text { [character] }\end{array}$ & $\begin{array}{l}\text { Human figure / a } \\
\text { man }\end{array}$ & 44 \\
\hline & $\mathrm{X}$ & - & - & Hands, feet & $\begin{array}{l}4 \\
4\end{array}$ \\
\hline & $\mathrm{X}$ & 16 & Scars & - & - \\
\hline & $\mathrm{X}$ & - & - & Rye blade & 8 \\
\hline & $\mathrm{X}$ & 40 & TV & - & - \\
\hline 11 & $\mathrm{X}$ & 4 & Graphics & - & - \\
\hline
\end{tabular}

If the results presented in both tables are compared, it can be concluded that, firstly, students have mentioned MAE representing almost all of the criteria groups (Table 1), missing only movement; secondly, the most popular MAE named by the pupils are similar to the criteria: the MAE referring to line (group 1) are named according to the rate $52 \%$ in the test version 1 and $26 \%$ in the test version 2. MAE referring to form (group 3) are named according to the rate $16 \%$ in the test version 1 and $8 \%$ in the test version 2. MAE referring to colour (group 6) are named according to the rate $80 \%$ in the test version 1 and $56 \%$ in the test version 2 . MAE referring to space have been named just according to the rate $4 \%$ because only in two posters space is perceptible, while the rate of naming MAE referring to composition is so low (respectively $16 \%$ in the test version 1 and $28 \%$ in the test version), because the assignment includes a separate question regarding the type and balancing of the composition. However, it should be concluded that the students who had taken the test version 1 have named MAE more successfully, for example, the detailed references to the applied colours (contrasting colors, flag colors, etc.), the usage of "headline" instead of the awkward "caption", and no black color has been mentioned. Here the question arises whether the emotional message or the information that the work bears can also affect the quality of the students' assessment. Indeed, in the second version, the posters represent a darker color gamut and the socio-political issues that the works present cannot be easily perceived (delivering messages of despair, distress, helplessness 
("Help!"). To comprehend the visual information expressed in the works, the students would need additional information and knowledge. Finally, the students have also named MAE that are not enlisted in the review of the means of visual expression and as such are characteristic to other art forms: metaphor, personification, etc. - no. 10; artistic images (man, pointer, sheep, etc. - see no. 11); types of art (graphics, photography, etc. see no. 12). These points reveal a lack of comprehension regarding MAE.

In recent years, a new phenomenon has been observed that did not previously appear in the test results at the subject "Visual Art" - students apply interdisciplinary knowledge and skills for dealing with their practical assignments, as proved by the study group of students of Riga Distance Education Secondary School in the study year 2017/2018 academic year. The students increasingly use literary means of expression, such as "personification" and "metaphor" for analyzing a work of visual or plastic arts. In particular, this phenomenon can often be observed in the analysis of multimedia works. This means that the students are increasingly using the knowledge and skills they have acquired elsewhere in different subjects or in new non-standard situations. That means that the students are able to select the necessary knowledge and apply it while working with another teacher or mastering different classes.

One of the creative tasks of the students is the creation of a graphic design sketch for a brand or logo. There are several conditions that must be met when designing a brand. In the study year 2017 / 2018 the conditions of the task for the pupils are as follows:

1) to create their own brand sketch on cultural events in Latvia and on the second version of the task - on tourism in Latvia;

2) one Latvian ornament pattern and other graphic means of expression (line, area, contrast, texture) must be incorporated into the brand image as in a balanced asymmetric or symmetrical composition;

3) work must be completed in at least two colors; text characters (letters and / or numbers) must be used;

4) work can be done in graphic pencil, color pencils, felt pens, ink pen, gel pen, the students can also use computer graphics tools if the work is done in computer graphics;

5) the sketch has to be signed before it is added to the test, the file must be named: Name, Family Name, Class, Number of the Test, Number of The Versio, Date.

In all the samples (Figure 5-10; it should be noted that, due to the General Data Protection Regulation, students' names and family names are not displayed), the means of artistic expression required by the terms of the assignment are used: line, field, contrast, texture. Two and more colors 
have been used in the works, and the pupils have successfully coped with the balance of the composition.

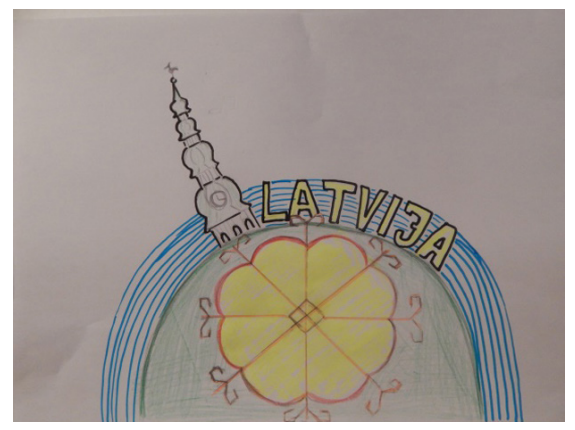

Figure 5. Year 10 student. Latvia. 2017. Paper, colour pencils, ink pen

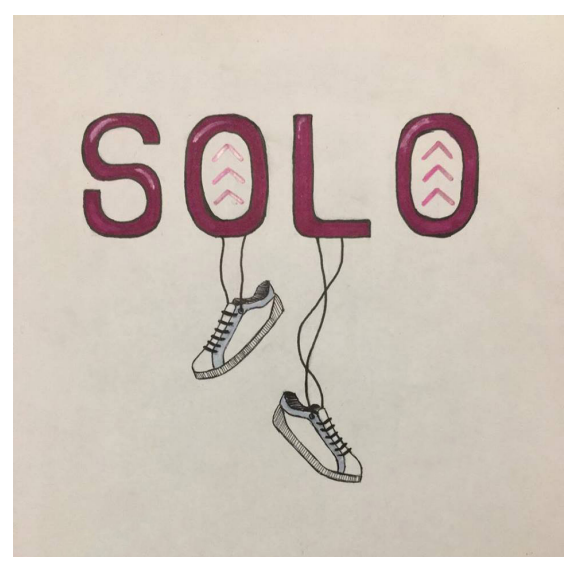

Figure 7. Year 10 student. Solo. 2017. Paper, colour pencils, ink pen

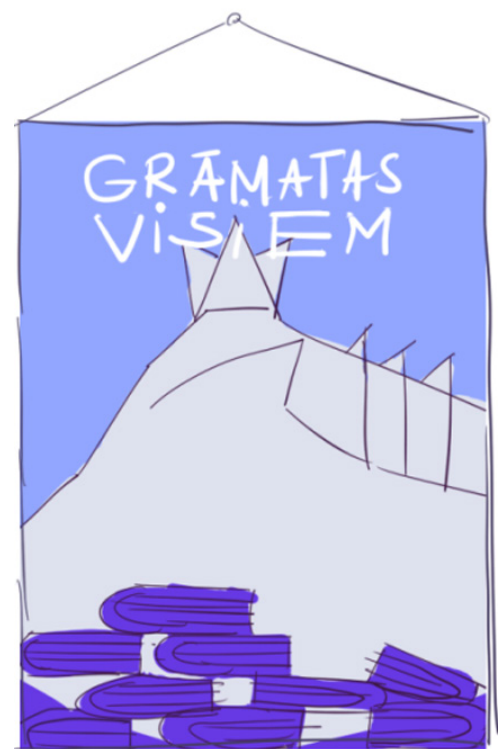

Figure 6. Year 10 student. Books For Everyone. 2017. Computer graphics

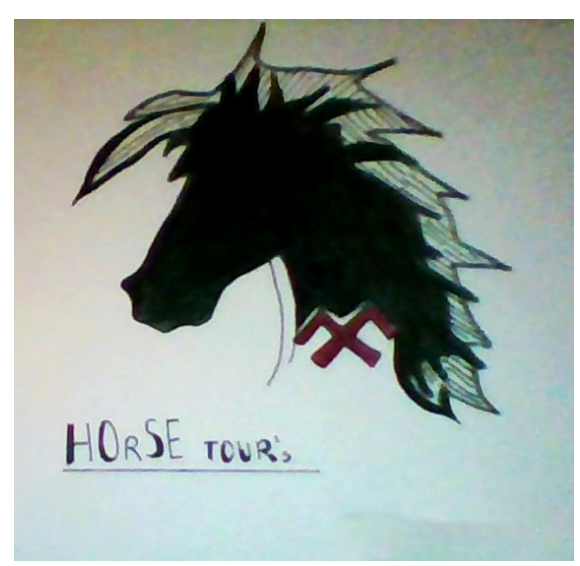

Figure 8. Year 10 student. Horse tour's. 2017. Paper, ink 


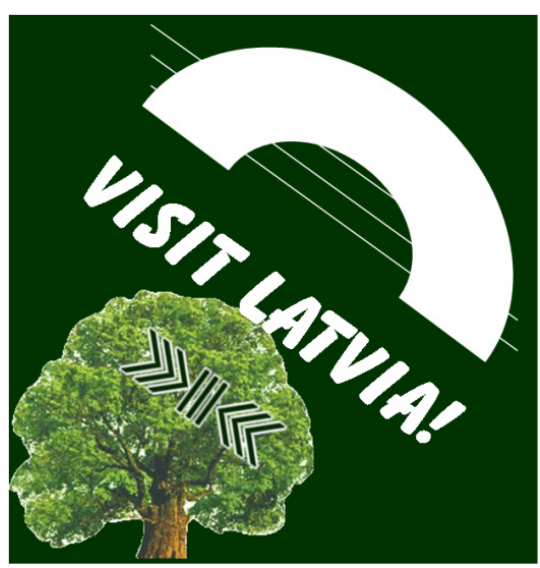

Figure 9. Year 10 student. Visit Latvia! 2016. Mixed technique

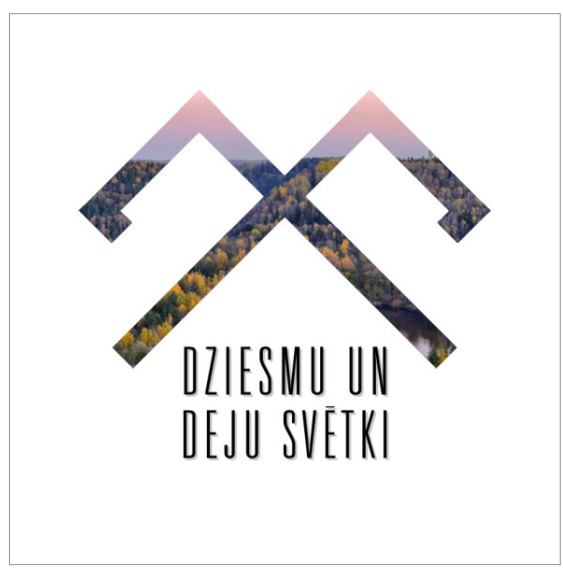

Figure 10. Year 10 student.

Song And Dance Festival. 2017. Computer graphics

However, there is a need to talk about phenomena that have arisen through electronic visual communication that require the utmost attention from the educator, as students sometimes present works by other authors. There was only one case of plagiarism (copyright infringement) in the study year 2017/2018. The teacher always responds and discusses the ethical and legal aspects of the student's action. The second most important problem in distance learning is the usage of computer graphic tools. In high school, the age of students ranges from 16 to undefined age (in the context of lifelong learning), and skills are developed at various stages of development. Performance skills, feelings, attitudes and other subjective and objective factors - all of which create new challenges or surprises for students and teachers in visual communication.

Let's also consider other pupils 'self-made creative tasks to further understand students' skills in visual communication. Admittedly, students create new means of visual expression (without realizing it) thanks to a phenomenon that is rapidly entering our professional and pedagogical work, namely information and communication technologies (hereinafter - ICT). In traditional pedagogical practice, students begin, finish and exhibit their work in interaction with and under the guidance of a teacher. Together with the teacher they discuss success and see improvement opportunities for the works to come. The specificities of distance learning are that the students are watching video or face-to-face lectures or webinars, then they independently do their creative work, then they take a picture (camera, smartphone, etc.), process the picture and send it electronically to the school's online system so that the teacher receives, views and grades it electronically. New distance learning opportunities allow one to exchange 
information electronically, which explains why new challenges and visual effects are created. This is a new possibility that can be ignored, however, when it comes to visual communication which "observes all the traditional media requirements" (Bergstrem, 2008), then nothing can be neglected or ignored. If the student communicates with the teacher using ICT, then the visualization of the creative work, or the image received by the teacher from the student, should be perceived as an original work of art, but bearing in mind that the final result of the student's production may look different from the initial idea. It can therefore be stated that the 'deviation' of a visual image resulting from a non-professional use of various digital devices creates new artistic means of visual expression.

Let's pay a closer look to these new visual means of expression or special effects that have been identified in a number of cases and tend to recur, such as a blurry image or blurred contoured image (Figure 11 and 15), too dark or too light image (Figures 11 and 12), intentionally lightened images or appliance of special color filters (Figures 16 and 21), appliance of additional shadow silhouettes appearing as new characters (intentionally or unintentionally) (Figures 14 and 18). As new characters also tools, setting supplies, hands, faces and even legs may appear (Figures $13,15,20$, and 23). Often (about $50 \%$ of the cases) non-perpendicular images are presented (Figures 13 and 18), which create an illusion of an additional perspective. The picture is sometimes framed with additional fields that create the illusion of a, often adding a different coloring to the work (Figures 12, 18 and 22). It should be noted that the students often decide to comment on their work with an additional description, although it is not required in the task description (Figures 18, 19 and 22). Since the students are quite free to choose the technique of their creative works, combined techniques may contribute to creating new visual effects such as glare (Figure 18). 


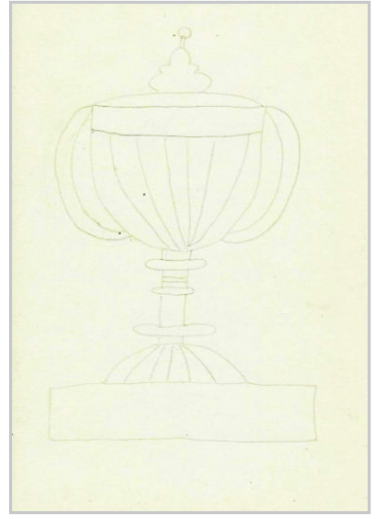

Figure 11. Year 11 student. Victory Cup. 2016. Paper, pencil.

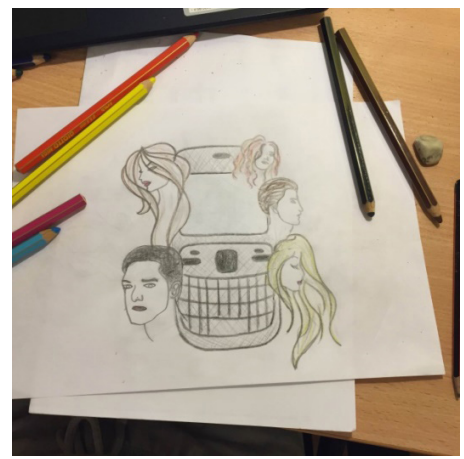

Figure 13. Year 11 student. Connection mania. 2016. Paper, colour pencils.

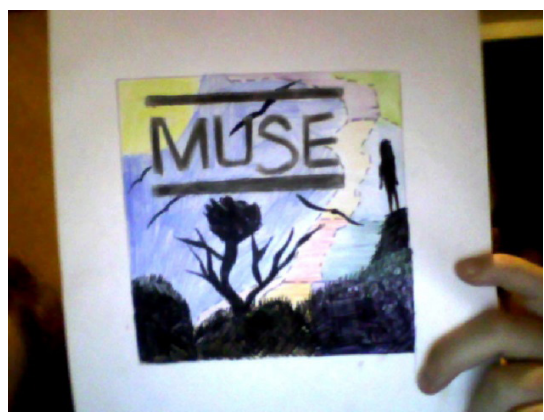

Figure 15. Year 9 student. MUSE. CD cover. 2015. Paper, colour pencils, felt pens.

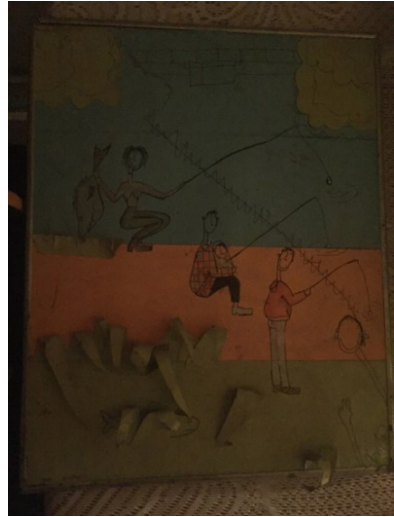

Figure 12. Year 11 student. Resting. Fishing. 2017. Paper, colour pencils, paper collage.

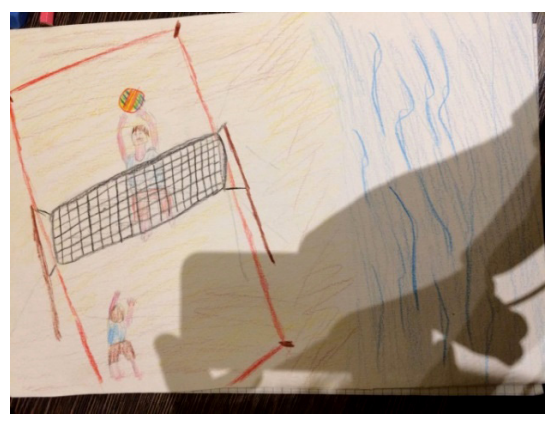

Figure 14. Year 11 student. Rest. 2017. Paper, colour pencils

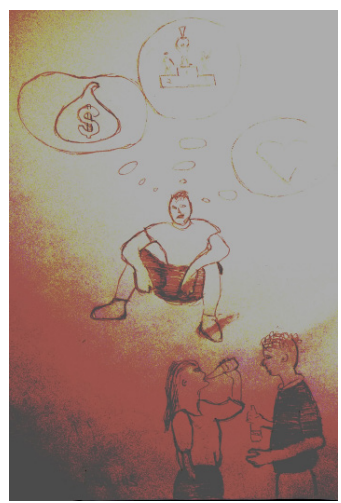

Figure 16. Year 11 student. Food for Thought. 2017. Paper, colour pencils, digital filter. 


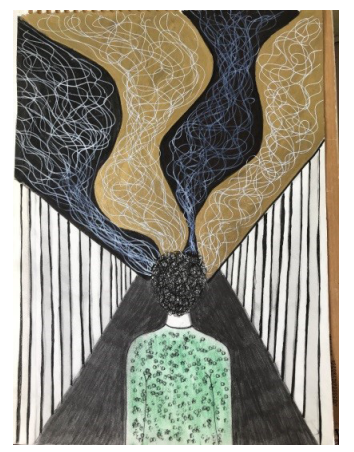

Figure 17. Year 12 students. Still Life. 2015. Pencil, golden gel pen.

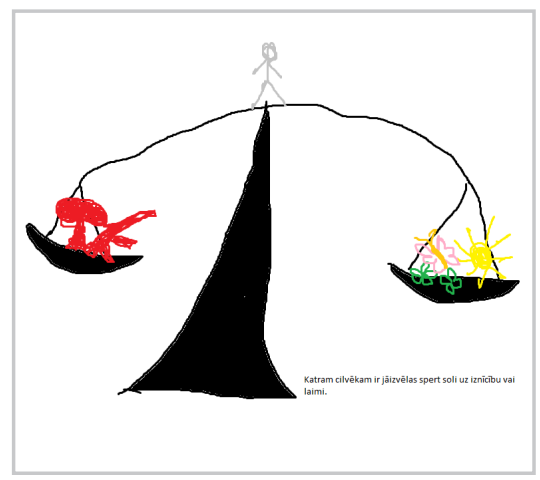

Figure 19. Year 11 student. Everyone must decide if they want to take a step towards destruction or happiness. 2015. Computer graphics.

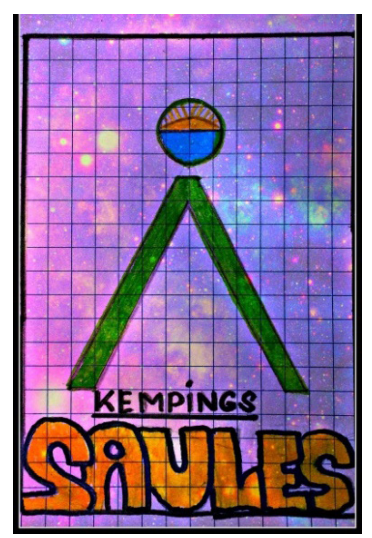

Figure 21. Year 11 student. Camping Sunshine. 2015. Felt pen, digital filter.

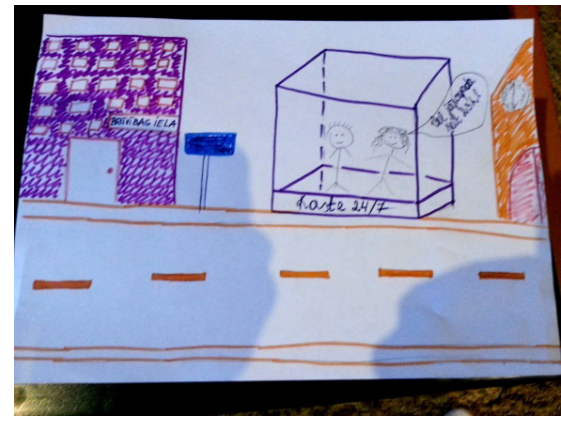

Figure 18. Year 11 student. The Box. 2017. Felt pen.

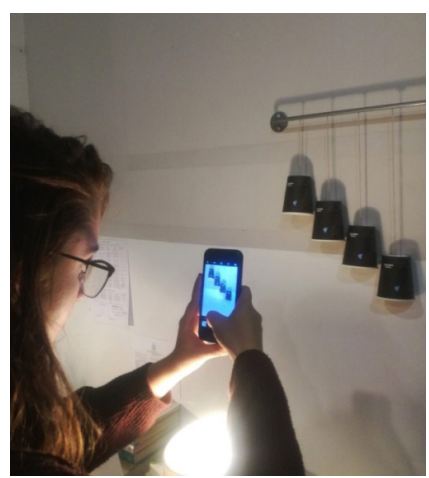

Figure 20. Year 10 student. Installation. 2018. Paper cups, stick, thread.

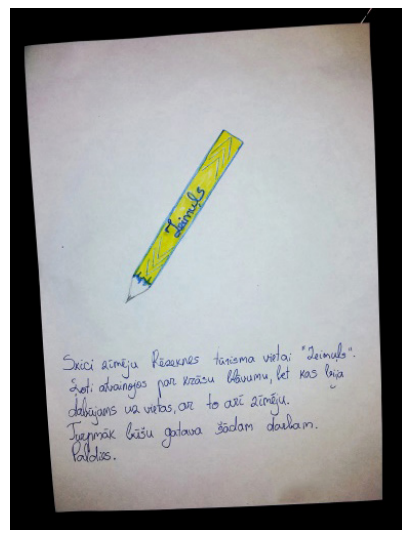

Figure 22. Year 11 student. Zeimuls (The pencil). 2017. Paper, colour pencils. 


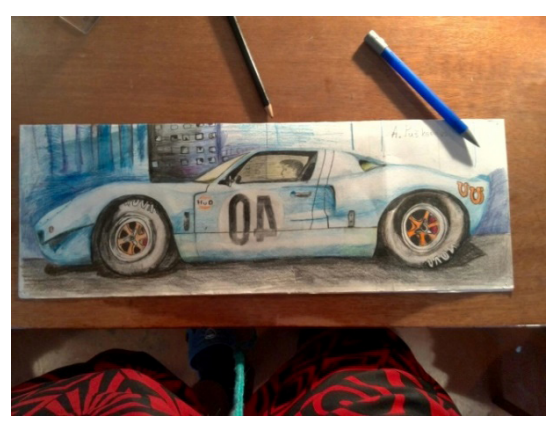

Figure 23. Year 11 student. Rest. 2017. Paper, colour pencils.

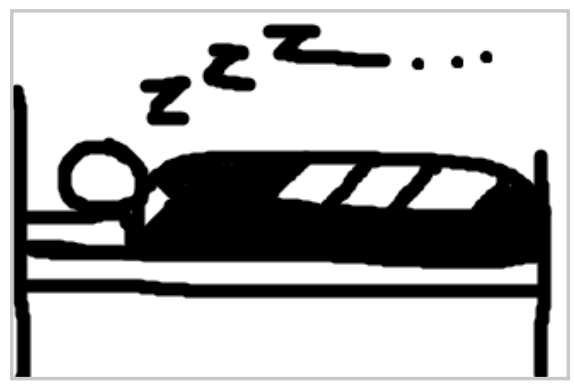

Figure 24. Year 11 student. To Sleep and To Dream. 2015. Computer graphics.

All the selected samples are noteworthy because they reveal the students' different perceptions of the world and their ability to visualize their experience, as well as they suggest the methodological tools that help to set the direction for improvements. It must be admitted that almost all the works are matching the set task requirements mentioned in the curriculum of the subject "Visual Arts", which is specially designed for distance learning. Very often the students have decided to visualise active recreation (Figures 11, 12, 14, 23 and 24), or local cultural and sociopolitical events (Figures 13, 15, 16, 18, 19, 20, 21, and 22); there are also works that reveal the feelings of the students; their actual emotional mood, or a desire to communicate with the teacher, such as "Abstract Self Portrait", "Human Figure Studies" or "Art Work Analysis" "(due to personal contents of the works I have decided not to share them for public access). Rarely, however, there are presented very daring works with visualization of political events (sketches, posters, comics, animations, etc.), popular bands or cartoons. Sometimes it seems that the students want to express something more than the actual image referring to themselves, to their work process, to their environment, or telling about the success or failures they meet when performing the assignment.

\section{Results of survey}

To answer the research question whether students can acquire visual literacy skills at a general secondary school (in distance learning conditions) at a level that enables them to apply the means of visual communication effectively by mastering and using visual means of expression, we can admit that the answer is affirmative. The variable regarding this issue is the visual means of expression themselves - the elements, either those traditional for the visual language, or the new ones that emerge from the 
usage of multimedia devices and will be developed more and more in visual communication. As Joseph Deken explains in his work "Computer Images: State of the Art", computer scripts lead to "an absolutely new type of visual communication that allows each viewer to individually tailor their intercommunicative activities" (Deken, 1983). The power and efficiency of computer generated images is achieved by the ability of the computer to memorize and process pixels or individual image elements. Computer generated image is a set of pixels arranged in rows and columns, similar to a mosaic. The computer remembers the location and colour characteristics of each pixel, and then processes them in different ways. Of course, this requires appropriate software (Berger, 1989). It is clear that the use of computer tools is inevitable in contemporary art education, so work with these tools also must be mastered parallelly and responsibly.

Students confidently name the most popular or traditional means of visual expression, as in the case with the reviewed textbooks. Comparing the results of Tables 1, 2 and 3, we have found a significant amount of similarities between the used teaching aids (TA) and the most important means of artistic expression (MAE). Graph 1 shows the percentage of MAE 'line' in TA and in students' responses. MAE ' line' has been rated by counting together MAE 'stripe', 'hatching' and 'outline' because of similar meanings. The least amount of having named the MAE 'line' (32\%) has been provided by the analysis of the poster $T V$-violence analysis, as some students referred to 'scars' (16\%) as a separate MAE, confirming the importance of emotional experience (pain) in the analysis, which would generally yield an equivalent outcome compared to other options.

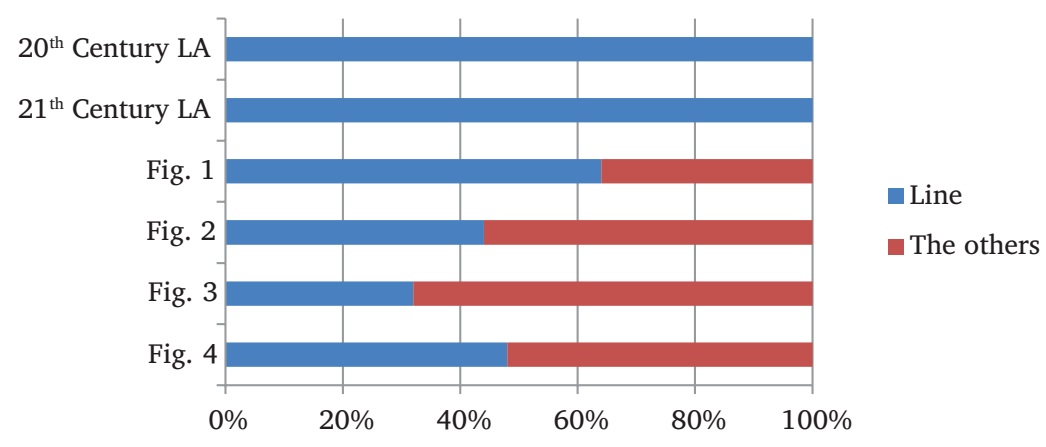

Graph 1. MAE 'line' in TA and students' works

Graph 2 shows the percentage of MAE 'colour' in TA and students' tests. MAE 'colour' is the most commonly mentioned MAE in students' work, 
especially if we count together all the MAE referring to colour such as opposite colour, red, yellow, blue colours, achromatic colours, etc. - in that case the percentage would exceed $100 \%$, especially in the images of the test version 1 . It can be stated that all the students recognize colour (except for those who do not mention MAE at all).

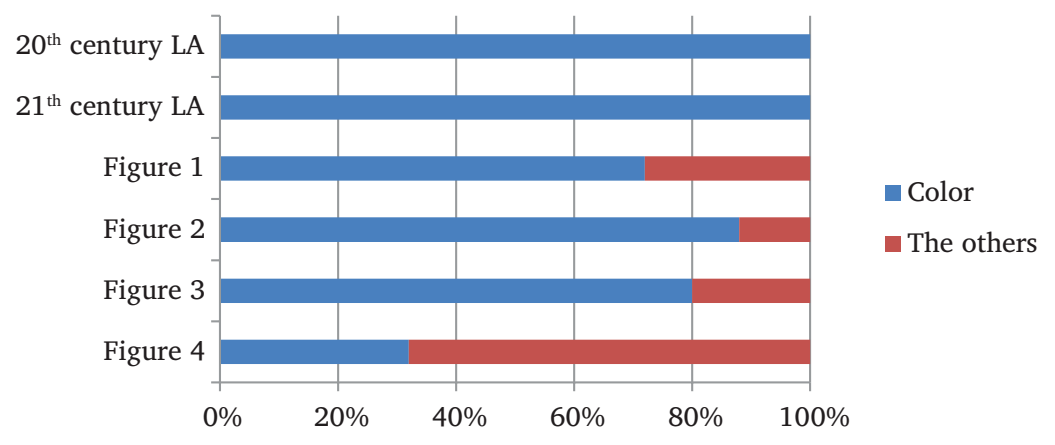

\section{Graph 2. MAE 'colour' in TA and students' works}

Graph 3 shows the percentage of MAE 'shape', mentioned in all the TA but rarely or not at all in the students' works. That could be explained with two reasons: either the students refer to MAE with similar meanings such as 'square', 'background', 'silhouette', 'frame' or 'screen', which together form as much as $68 \%$ (test version 1); or the concept of 'form' is very unclear, requiring additional explanation, which might be the reason why students avoid it.

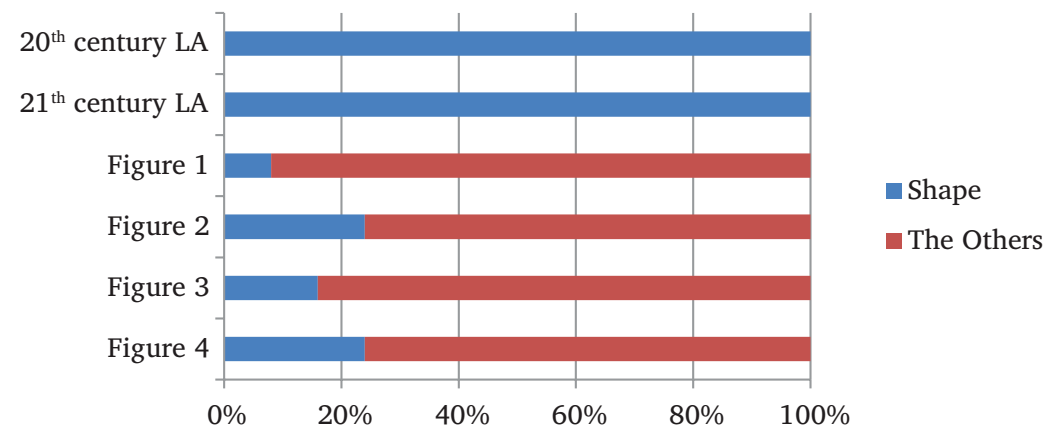

Graph 3. MAE 'shape' in TA and students' work

Nonetheless, the MAE 'letter' or 'text' presented by the students has been mentioned only in the most recent teaching aids of the 21st century. 
It is described in more detail in Matīss Kūlis book, Chapter 4 - "Artistic Expression Tools for Communication Development" where the author discuss letters, fonts and the aesthetic importance of text in the subchapters "Text and Image" and "Graphic Design of Fonts". We have to agree with Matīss Kūlis, who argues that there have never been so many character styles in the history of mankind as in the 21st century" (Kūlis, 2015).

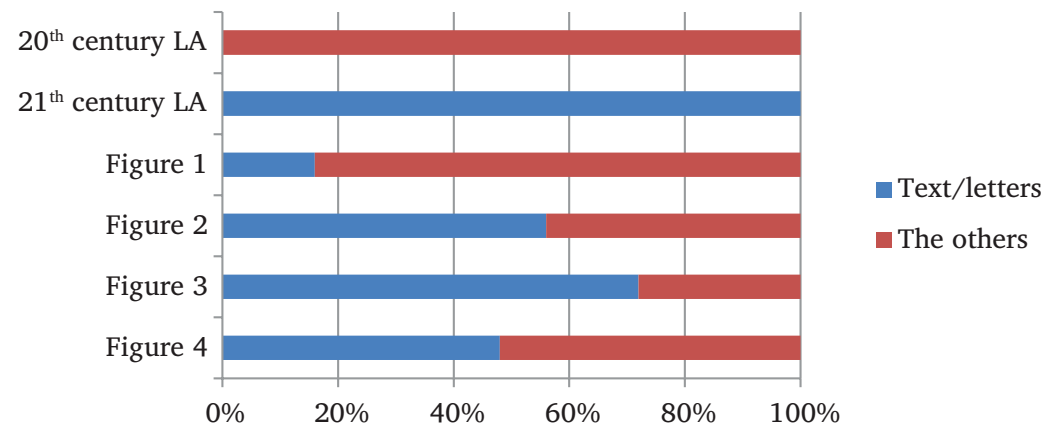

Graph 4. MAE 'text/letters' in TA and students' works

\section{Conclusions}

Teachers obviously have to adapt to the requirements of their time and help students in their creative quest. However, we have to bear in mind that if the assignment had been based on drawing/painting evaluation assessment exclusively, letters/text would play no role at all.

Besides traditional visual means of expression, such as line, field, contrast, color, light, space, texture, the students also use the "new" means of expression or visual effects in their creative works (intentionally or unintentionally), which clearly draw the attention of the teacher claiming for a further development of pedagogical practice. Let's name the identified new visual means or special effects:

- blurry images or images with blurred contours - 'fog effect' (Blood, 2015);

- too dark or too light images;

- special colour effects (reflections, luminescent colors) applied in images;

- appliance of additional shadow silhouettes appearing as new characters (intentionally or unintentionally);

- As new characters also tools, setting supplies, hands, faces and even legs may appear;

- Non-perpendicular images (as opposed to frontal - inclined); 
- images with framed additional fields (frame, extra background);

- An image with a comment or an additional description on the image.

The teacher faces several challenges when they encounter these new means of artistic expression: firstly, whether to evaluate the whole picture, or only the part that the student has created on paper or another material, or the final photo, which has been submitted electronically; secondly, the teacher needs to reflect on ways how to deliver a feedback so that the pronounced (written) conclusion or suggestion does not hurt the student, but motivates him/her for a new creative learning process; third, the teacher needs to assess the performance of the students attentively, to group them by qualitative and quantitative similarities, and to build their own portfolio to develop new tests and creative assignments successfully.

The teacher's task is to improve his/her professional skills constantly to be able to view these cases as something new and unprecedented, to be able to marvel at them and still to be able to comment on them professionally, seeing the student's creativity and potential for growth, so that the student would be encouraged to meet new challenges. In this way, successful reciprocated communication between the student and the teacher would be developed (Bergstrem, 2008).

The only subquestion that remains unanswered is whether a hand-drawn line (created by an unprofessional and untrained hand) can compete with the precision of a compyter. Michael Noll (in the catalogue of SIGRAPH) admits: "Computer technologies are completely conquering those fields of visual art where the artistic potential has not been fully developed. Computers (ICT) are used to create new visual images, but several viewers are left with the feeling that something is missing. Computer images sometimes look as if parodying other means of expression. Many of them are cold and sterile, often having lost the expression of being alive" (Noll, 1982). The expressive emotional drawing made by a student him/herself will always be more attractive than a graphic developed by a computer software, as the former allows not only to observe the dynamics of the development in a student's drawing, but also the development of their creative abilities.

The study allows us to conclude that by analyzing the artworks and means of artistic expression in them students can discover both traditional and new means of visual expression and the principles of their organization in an artwork as well as recognize the factors and cultural contexts (signs) that influence the perception of a work of art, such as symbols, archetypes, messages, etc. They can discover new means of expression in works of art and in their own creative works without losing ethical and aesthetic qualities, while developing creative and critical thinking that helps them to overstep the limitations of the task requirements. 
Distance learning students gain interdisciplinary knowledge and skills that stretch over different subjects. The development of art education today is influenced by several paradigms: postmodernism, multiculturalism, feminism, social values, semiotics, deconstruction, and other factors, as stated by art education theorists Michael Day and Al Hurwitz in the methodical material "Children and Their Art" (Day, Hurwitz, 2012). Despite the difficult conditions in which pupils in Riga Distance Learning Secondary School acquire art education (remotely and in self-directed studies), they are able to communicate, to observe, to perceive, to develop ideas, to analyze, to describe, to consider, to project, to sketch, to anticipate, to experiment, to enjoy, to interpret, to present and to appreciate - in other words, their skills prove that they possess visual literacy that consists of the ability to create and react, just as it is stated in the European Union's basic principles of lifelong learning.

\section{References}

\section{Printed materials}

1. Berger, A. (1989). Seeing is believing: An introduction to visual communication. Mountain View, Calif: Mayfield Pub. Co.

2. Bergstrems, B. (2008). Vizuālā komunikācija [Visual Communication]. Riga: Janis Roze Publishing house, 240.

3. Blūma, D., Šmite, E. (1998). Kā top glezna, gravīra, skulptūra. Eksperimentālais metodiskais lïdzeklis [How painting, engraving, sculpture are made. Experimental methodological tool]. Riga: Publishing house "Mācību grāmata", 64.

4. Briška, I., Kadiḳe, I., Kalēja-Gasparoviča, D., Rudovska, M. (2009). Vizuālā māksla vidusskolai. 1. dala [Visual Art for High School. Part 1.]. Riga: Publishing house "Izdevniecība RaKa", 100.

5. Briška, I., Kadiķe, I., Kalēja-Gasparoviča, D., Rudovska, M. (2010). Vizuālā māksla vidusskolai. 2. dala. [Visual Art for High School. Part 2.]. Riga: Publishing house "Izdevniecība RaKa", 87.

6. Day, H, Hurwitz, a. (2012). Children and Their Art. Art Education for Elementary and Middle Schools. $9^{\text {th }}$ esdition. US: Wadsworth Cengage Learning, 414.

7. Hibnere, V., Grasmane, L., Villerušs, V. (1985). Tēlotāja māksla 1.-6. Klasē. Izteiksmes lidzekli un tehnika. [Fine Arts in Grades 1-6. Means of expression and technique]. Riga: Publishing house "Zvaigzne", 88.

8. Wagner, E., Schönau, D. (2016). Common European Framework of Reference for Visual Literacy - Prototype Münster · New York: Waxmann, 400.

9. Kahane, J. (2015). How Your Brain Understands Visual Language. Available: http:// www.fastcodesign.com/3047340/how-your-brain-understands-visual-language., viewed January 25, 2018.

10. Kūlis, M. (2015). Saskarñu māksla. Datori. Grafika. Dizains [Interface art. Computers. Graphics. Design.]. Riga: Author's edition. 131. 
11. Mitchel, W. J. T. (1980). The Language of Images. Chicago: U of Chicago P, 1980. pbk.

12. Tēlainās izteiksmes līdzekḷi - tēlošanas panēemieni mākslā. Ilustrētā svešvārdu vārdnīca [Means of imaginative expression - techniques of art. Illustrated foreign vocabulary]. (2005). Compiled by I.Andersone etc. Riga: Publishing house "Avots", 375.

13. Zirdziña, V. (1995). Vizuālās mākslas valodas ĀBECE [Visual Arts Languages ABCE]. Riga; Publishing house "Sprīdītis". 96.

\section{Article from an Online Periodical}

1. Republic of Latvia Cabinet. (2013). Regulations Regarding the State General Secondary Education Standard, Subject Standards and Sample Education programmes. Regulation No. 281 adopted 21 May 2013. Downloaded from: https://likumi.lv/ doc.php?id $=268342$

2. Republic of Latvia Cabinet. (2018). Regulations on the National Standard for Basic Education and Models of Basic Education Programs. Regulation No. 747 adopted 27 November 2018. Entry into force in 2020. Downloaded from: https://likumi.lv/ ta/id/303768-noteikumi-par-valsts-pamatizglitibas-standartu-un-pamatizglitibasprogrammu-paraugiem

3. Ministry of Environmental Protection and Regional Development, (2010). Sustainable Development Strategy for Latvia 'Latvija 2030", Downloaded from: http:// www.varam.gov.lv/lat/pol/ppd/?doc $=13857$

4. Ministry of Environmental Protection and Regional Development, (2012). National Development Plan 2014 -2020. Downloaded from: http://polsis.mk.gov.lv/ documents/4247

5. Republic of Latvia Cabinet. (2014). CULTURAL POLICY GUIDELINES 2014-2020 "CREATIVE LATVIA" (Informative Part). Downloaded from: https://likumi.lv/ta/ en/en/id/267970

6. UNESCO in Latvia. (2016). Latvijā viesojas mākslas izglitïbas eksperts Ernsts Vāgners [Art education expert Ernst Wagner is visiting Latvia]. Downloaded from: http://www. unesco.lv/lv/jaunumi/latvija-viesojas-makslas-izglitibas-eksperts-ernsts-vagners/

7. Project Skola 2030. (2017). Izglìtiba mūsdienigai lietpratïbai: mācìbu satura un pieejas apraksts [Education for Contemporary Competence: A Description of Curriculum and Approach]. Downloaded from: https://www.izm.gov.lv/images/aktualitates/2017/ Skola2030Dokuments.pdf

8. Kahane Josiah. (2015) Publication - How Your Brain Understands Visual Language. Downloaded from: https://www.fastcodesign.com/3047340/ how-your-brain-understands-visual-language

9. Valsts izglitibas satura centrs [National Center for Education] (2011). Vizuālā māksla vidusskolai. Metodiskais materiāls. [Visual Art for High School. Methodological material]. Downloaded from: http://www.talmacibasvsk.lv/lv/programmas/ videja-vispareja-izglitiba 